\title{
An Overview of Matrix Metalloproteinase 9 Polymorphism and Gastric Cancer Risk
}

\author{
Sugreev Verma ${ }^{1}$, Kousik Kesh ${ }^{1}$, Arnab Gupta ${ }^{2}$, Snehasikta Swarnakar ${ }^{1 *}$
}

\begin{abstract}
Matrix metalloproteinase (MMP) 9, a key member of multifunctional family of zinc dependent endopeptidases has been found to be upregulated during inflammation and in some cancers. MMPs cleave extracellular matrix (ECM) proteins and play critical roles in cellular apoptosis, angiogenesis, tumor growth and metastasis. Several genetic polymorphisms have been identified that show allele specific effects on MMP9 regulation and are associated with gastric cancer, the fourth most common malignancy in the world. Besides Helicobacter pylori infection, genetic predisposition is another documented risk factor for gastric carcinoma. The single nucleotide polymorphism (SNP) at position -1562C/T of MMP9 results in the modulation for binding of transcription factors to the MMP9 gene promoter and thereby causes differences in protein expression and enzymatic activity. MMP9 transcriptional regulation during gastric cancer development remains poorly known although several studies have demonstrated associations between MMP9 -1562 C/T polymorphism with different diseases. Knowledge on mechanisms of MMP9 upregulation during gastric cancer may provide new paradigm in diagnostics and therapeutics.
\end{abstract}

Keywords: Gastric cancer - matrix metalloproteinase 9 - single nucleotide polymorphism - case control study.

Asian Pac J Cancer Prev, 16 (17), 7393-7400

\section{Introduction}

During 1980s the most frequent type of cancer was the cancer of stomach (Wu et al., 2002). Until recently stomach cancer is the second most cancer worldwide with approximately 870,000 new cases per year (Sentani et al., 2008; Ferlay et al., 2010). Gastric cancer incidence rates vary up to ten fold throughout the world. Nearly two third of gastric cancers occur in developing countries (Crew and Neugut, 2006). However, gastric cancer remains a prevalent cancer in eastern part of the world; Taiwan. Gastric cancer ranks as the fourth highest cause of cancer related death with a mortality rate of 10.72 per 100000 (Wu et al., 2002). In India, nearly one million new cancer cases were estimated in recent years (Murthy et al., 2008).

Although the incidence of gastric cancer is declined in western countries but it remains fourth most common cancer worldwide. The decrease in the incident of gastric cancer is associated with standard of living, proper dietary habits and adequate intake of vitamins. Over the past years, a great deal of research has clarified the details of genetic and epigenetic abnormalities related to gastric cancer development (Choi and Wu, 2005). Infection with $H$. pylori is the major cause for pathogenesis of gastric cancer. Smoking and tobacco intake doubles the risk for gastric cancer development. Moreover, genetic predisposition, diet, stresses and environmental factor accounts for other risk factors.

MMPs are essential regulators of the microenvironment of the cell through there capability of degrading ECM which is considered as a barrier in cellular invasion (Sternlicht and Werb, 2001). MMPs are synthesized as inactive zymogens (pro-MMPs) by several types of cells and become activated in the extracellular space by other MMPs or serine proteases including plasmin (Inuzuka et al., 2000). The ECM of the gastric mucosa is composed of a number of macromolecules, such as collagen, laminin, proteoglycan, elastin, fibronectin and hyaluronic acid, and their degradation by MMPs plays an important role in maintaining the cellular microenvironment (Hellmig et al., 2006). MMP9 (92- kDa, type IV collagenase) located on human chromosome 20q11.1-13.1 (Fig1), is a key enzyme in the causation of gastric ulcer (Swarnakar et al., 2005; Kundu et al., 2006). MMP9 (also known as gelatinase B) can degrade collagen type IV, collagen type V and elastin as well. MMP9 is mainly expressed by alveolar macrophages, polymorphonuclear leukocytes, osteoclasts and malignant cells (Fanjul-Fernández et al., 2010). Under pathological conditions including gastro-intestinal inflammation and gastric cancer, enhanced level of MMP9 has been described. Increased expression of MMP9 mRNA has been documented in primary tumor and metastatic tissues of gastric cancer (Sier et al., 1996). H. pylori infection of gastric carcinoma cells showed increased 
mRNA and protein level of MMP9 (Fox and Wang, 2007). Increased MMP9 expression and transcription that might be the result of diminished repressor binding to the promoter region. A comprehensive literature survey revealed that MMP9 SNP was significantly associated with various diseases being cardiovascular diseases rank first and stomach diseases rank sixth (Fig2).

Several epidemiologic studies revealed the association of MMP9 and development as well as progression of gastric cancers in different populations (Sier et al., 1996; Zhang et al., 2012). Over expression of MMP9 has been observed in a variety of cancer including gastric cancer and its expression is associated with pathological features, such as TNM stage, lymphatic invasion, tumor depth (Zhang et al., 2003). Tan et al reported that the serum MMP9 level increased gradually along with the depth of tissue invasion in gastric cancer patients (Tan et al., 2007).

\section{Various Polymorphisms of MMP9}

Genetic polymorphism describes existence of two or more different genotype or allelic variant in a population. SNP is the most common DNA sequence variation, which accounts for 1 in 100 in the genetic polymorphism. Genetic polymorphisms of MMPs are being increasingly recognized in the context of etiology and pathogenesis of gastric cancer. In human genome, the estimated number of SNP is 10 million while a small part is functionally relevant. Functional SNPs are mainly located in the promoter region. However, most of the studies showed that polymorphisms in MMP9 promoter region are more relevant to disease progression (Langers et al., 2011). In normal physiological conditions, genes are tightly regulated by transcription factors, whereas in cancer, aberrant activities of transcription factors deregulate the gene expression, leading to metastasis (Libermann and Zerbini, 2006). Therefore, the comprehensive knowledge of transcription factor binding sites (TFBS) in promoter region is essential for inferring gene regulatory networks (Hannenhalli, 2008). The manner and extent to which genetic factors contribute to disease have important implications for identifying the genetic basis of etiology and for utilizing this information for the diagnosis and therapies. Complex human diseases like cancers show relatively mild phenotype and are slowly progressive and chronic in nature.

Furthermore, the pathology is usually not clinically evident until in advanced stages. Complex diseases are typically polygenic and might have multiple gene associations, which individually have weak effects but when combined with each other and external influences, such as environmental factors, result in variable disease manifestation. The reasons behind an association of a disease phenotype with a haplotype instead of individual polymorphism are i) a functional effect on gene expression is dependent on interaction between two or more polymorphism ii) generally haplotype has a higher probability than individual polymorphisms of showing useful linkage disequilibrium with an unknown causal variant.

To date, most studies focus on "functional" SNPs, but the number of SNPs with clear function is limited and incorporating SNPs in studies of cancer predisposition and prognosis to find out the true association are still challenging tasks. Regulatory SNPs, which are in the promoter region specifically, alter the binding affinity of transcription factor to DNA and in turn contributing to disease phenotype..

MMP9 gene promoter contig sequence confirmed the polymorphism positions -108 [(CA)n repeats $]-1562 \mathrm{C} / \mathrm{T}$,1831T/A and $-1932 \mathrm{C} / \mathrm{T}$. A cytosine (C) to thymine (T) transition at nucleotide -1562 in the promoter of MMP9 gene generates low activity for $\mathrm{C} / \mathrm{C}$ and high activity for $\mathrm{C} / \mathrm{T}$ and $\mathrm{T} / \mathrm{T}$ genotypes in gene transcription. In addition, there are polymorphic positions in the coding region of MMP9 as reported in different studies, for example R279Q, P574R, R668Q sites are documented in MMP9 structural region (Hu et al., 2005; Tang et al., 2008).

The distribution of genetic variants of MMP9 in Indian population was found to be different than that in Japanese, Korean, Chinese, Caucasian and AfricanAmerican populations (Hirakawa et al., 2003; Kubben et al., 2006; Woo et al., 2007; Xing et al., 2007; Lee et al., 2009). Recently, haplotype-based association study has been proposed as a powerful and comprehensive approach to identify causal genetic variation underlying complex diseases. Figure1 shows pictorial depiction of SNPs in MMP9 gene covering 13 different SNPs in 5' UTR, 29 SNPs in structural gene and 11 SNPs in 3' UTR.

\section{Gastric Cancer Risk and MMP9 Polymorphisms}

MMPs alter the tumor microenvironment and may affect the process of carcinogenesis and, they appear to be induced through transcriptional activation (Ye et al., 1996). Being a member of MMP family, MMP9 has been reported to play an important role in cancer invasion through their over expression, which is associate with metastasis and unfavorable prognosis in gastric cancer (Inoue et al., 1999; Kanamori et al., 1999; Ghilardi et al., 2001). Degradation of basement membrane is one of the major characteristics of gastric cancer, and is mediated by different MMPs, including MMP9. Invasion of surrounding structure and lymphatic metastasis are the main factors influencing the prognosis and survival of gastric cancer patients (Zhang et al., 2004a). Various studies revealed the association of MMP9 variants and risk of gastric cancer development

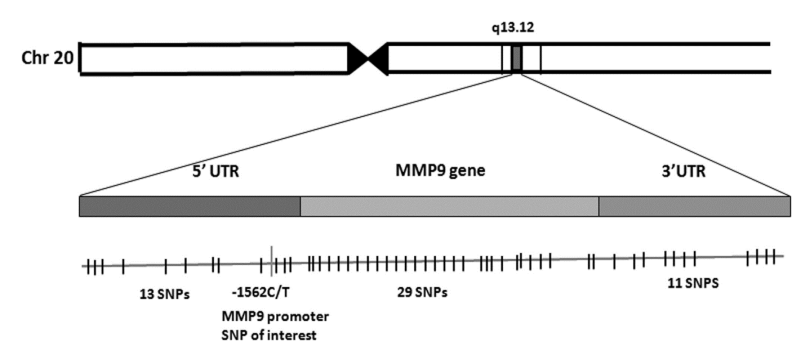

Figure 1. MMP9 Gene Polymorphisms. Schematic representation of human chromosome 20 and location of MMP9 gene. MMP9 SNPs on human chromosome 20q13.12 was adapted from UCSC Genome Browser (http://genome.ucsc.edu/ cgi-bin/hgGateway) 
and progression (Langers et al., 2011).

Recent studies have demonstrated that degradation of ECM and basement membrane by MMPs play an important role in tumorigenesis by modulating cell proliferation, apoptosis, and host immune surveillance, tumor invasion and metastasis (Kohn and Liotta, 1995; Forget et al., 1999). The polymorphisms of MMPs either in separate or combination are closely correlated with gastric cancer risk with age, sex and addiction. MMP9 -1562 C/T genotyping was performed by PCR-RFLP analysis using Sph1 restriction endonuclease (Figure 3). Subjects with MMP9 -1562 CT or TT genotype were at higher risk of gastric cancer as compare to MMP9 -1562 CC genotype in eastern Indian populations (Table 1). There is direct evidence of higher promoter activity of CT or TT allele as compared $\mathrm{CC}$ allele, thus allowing more transcription of MMP9 gene for CT/CT individuals. Table 1 shows the association of MMP9-1562 C/T polymorphism with gastric cancer risk. A total of 463 samples from patients with gastric cancer and control were examined in the study for the genotyping of MMP9 promoter. Patients with higher age group (> 50 years), with CT genotype displayed a significant difference in distribution than controls and associated with significant risk for gastric cancer development $(\mathrm{p}=0.001, \mathrm{OR}=1.841, \mathrm{CI}=1.267-2.68)$. The $-1562 \mathrm{C} / \mathrm{T}$ SNP located at the promoter of MMP9 is considered as potential genetic factor for progression of gastric cancer because it directly affects the transcription of MMP9 gene (Matsumura et al., 2005).

The MMP9 gene promoter contains binding sites for AP-1, NF-kB, Sp-1 and Ets-1 transcription factors (Gum

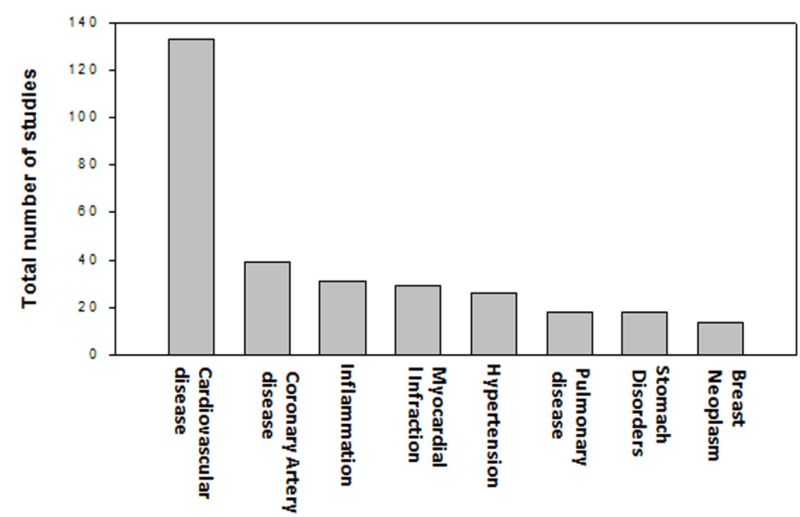

Figure 2. MMP9 SNPs and Major Diseases: A Survey of HUGE Navigator. MMP9 SNP was significantly associated with various diseases being cardiovascular diseases rank first and stomach diseases rank sixth
DOI:http://dx.doi.org/10.7314/APJCP.2015.16.17.7393 An Overview of MMP9 Polymorphism and Gastric Cancer Risk et al., 1996). In particular, Ets-1 expression always up regulated together with MMP9 (Behrens et al., 2001), and this up regulation correlates with tumor invasion in gastric cancer (Nakayama et al., 1996). MMP9 -1652 $\mathrm{C} / \mathrm{T}$ polymorphism is located within a transcription factor binding site, and this -1562 MMP9 locus has been investigated as regulatory element binding site for a transcriptional repressor protein, and the " $\mathrm{T}$ " allele results the loss of binding of the repressor protein and increased transcriptional activity (Zhang et al., 1999). MMP9-1562C/T promoter polymorphism has profound impact on progression and invasion of gastric cancer in Japanese population.

Polymorphism -1831 MMP9 polymorphism shows a cis regulatory effect on MMP9 expression which may be capable to bind GATA factor, master regulatory transcription factor for differentiation and perpetuation of human Th2 cells (Pinto et al., 2010). There are several important transcription factors binding site at MMP9 -90 (CA)14-23 including a GC box and NF-kB binding site (Shimajiri et al., 1999; Maeda et al., 2001). A study on CA polymorphism indicated that longer CA repeats were associated with greater transcriptional activity (Shimajiri et al., 1999). In addition, the (CA)n polymorphism patterns

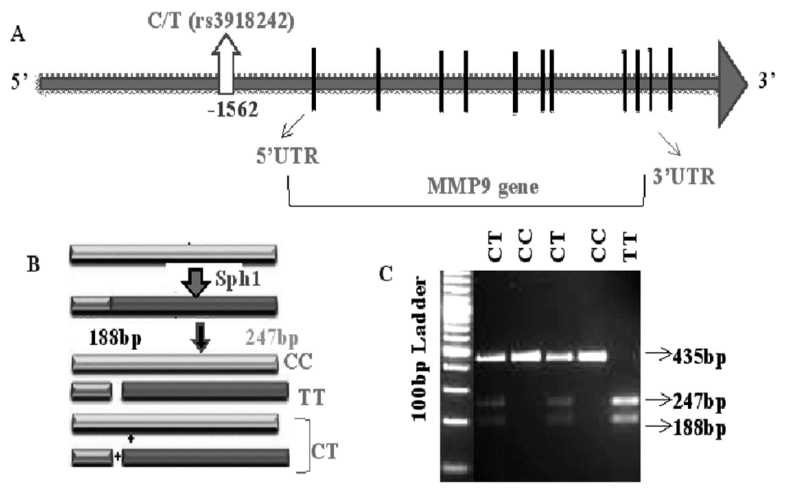

Figure 3. Genotyping of MMP9 -1562 C/T Polymorphism. (A) Schematic representation of MMP9 gene showing -1562 C/T polymorphic site, 5' UTR, MMP9 structural gene and 3' UTR. (B) Pattern of fragments generated upon Sph 1 digestin of different allele. (C) PCR-RFLP analysis of MMP9 -1562 C/T polymorphism showing all possible combination of different DNA fragments after restriction digestion by Sph 1. PCR amplicons of $435 \mathrm{bp}$ of MMP9 gene promoter were subjected to restriction digestion by Sph 1 , which cleaves the $\mathrm{T}$ allele and generates the fragments of $247 \mathrm{bp}$ and $148 \mathrm{bp}$ but leaves the A allele intact. Genotypes of the samples are shown above and arrows indicate molecular weights of different fragments

Table 1. Analysis of Association between MMP9 -1562C/T Polymorphism and Gastric Cancer Risk in Eastern Indian Populations

\begin{tabular}{lccccccc}
\hline Genotype & \multicolumn{2}{c}{ GC Patient } & \multicolumn{2}{c}{ Controls } & OR & 95\% CI & P value \\
& $\mathrm{n}$ & $\%$ & $\mathrm{n}$ & $\%$ & & & \\
\hline MMP9 (-1562C/T) & 230 & & 233 & & & & \\
CC & 108 & 46.9 & 143 & 62.17 & 1 (Ref) & & \\
CT & 114 & 49.5 & 82 & 35.1 & 1.841 & $(1.261-2.68)$ & 0.001 \\
TT & 8 & 3.4 & 8 & 3.4 & 1.324 & $(0.48-3.64)$ & 0.611 \\
CT+TT & 122 & 53.04 & 90 & 38.6 & 1.795 & $(1.24-2.59)$ & 0.002 \\
\hline
\end{tabular}

Odd ratio (OR) was calculated by binary logistic model using Graph pad In stat software to measure the strength of association of disease occurrence. $\mathrm{p}$ value was calculated by chai square to know significance in the distribution of genotype between patient and control. Significant values are shown in bold. $\mathrm{CI}=$ confidence ratio, $\mathrm{Ref}=$ Reference genotype for calculation of $\mathrm{OR}$ 
Table 2. Association of MMP9 -1562 C/T Polymorphism and Risk of Gastric Cancer in Various Ethnic Population

\begin{tabular}{|c|c|c|c|c|c|c|c|c|c|}
\hline $\begin{array}{l}\text { Author, } \\
\text { Year }\end{array}$ & Journal & Country & $\begin{array}{l}\text { SNP posi- } \\
\text { tion }\end{array}$ & $\begin{array}{l}\text { Genotype } \\
\text { assay }\end{array}$ & $\begin{array}{l}\text { Subjects } \\
\backslash \text { (Case/ } \\
\text { Cont) }\end{array}$ & $\begin{array}{l}\text { Study param- } \\
\text { eter }\end{array}$ & Principle finding & $\begin{array}{l}\text { OR (Odd } \\
\text { Ratio) }\end{array}$ & $\begin{array}{l}95 \% \mathrm{CI}(\mathrm{P} \\
\text { value })\end{array}$ \\
\hline $\begin{array}{l}\text { Zhang } \\
\text { XM } \\
2004\end{array}$ & $\begin{array}{l}\mathrm{Ai} \\
\text { Zheng }\end{array}$ & China & $-1562 \mathrm{C} / \mathrm{T}$ & $\begin{array}{l}\text { PCR-HPLC } \\
\text { PCR-RFLP }\end{array}$ & $228 / 774$ & Cancer risk & $\begin{array}{l}\text { No association with } \\
\text { cancer risk }\end{array}$ & & \\
\hline $\begin{array}{l}\text { Mat- } \\
\text { sumura } \\
2005\end{array}$ & & Japan & & $\begin{array}{l}\text { PCR-RFLP } \\
\text { Sequencing }\end{array}$ & & & $\begin{array}{l}\text { No link with cancer } \\
\text { risk. T allele as- } \\
\text { sociated with tumor } \\
\text { invasion, lymphatic } \\
\text { invasion and clini- } \\
\text { cal stage. }\end{array}$ & $\begin{array}{l}\mathrm{CT}+\mathrm{TT} \text { vs } \\
\mathrm{CC} \\
2.61 \\
\mathrm{CT}+\mathrm{TT} \text { vs } \\
\mathrm{CC}=2.27 \\
\mathrm{CT}+\mathrm{TT} \text { vs } \\
\mathrm{CC}\end{array}$ & $\begin{array}{l}1.07-6.34 \\
-0.03 \\
1.09-4.74 \\
-0.02 \\
1.12-4.55 \\
-0.02\end{array}$ \\
\hline
\end{tabular}

\begin{tabular}{|l|l|l|l|l|l|l|l|l|}
\hline & $\begin{array}{l}\text { British J } \\
\text { Cancer }\end{array}$ & Netherland & $-1562 \mathrm{C} / \mathrm{T}$ & PCR-RFLP & $79 / 169$ & $\begin{array}{l}\text { Cancer risk } \\
\text { Tumor re- } \\
\text { lated survival }\end{array}$ & $\begin{array}{l}\text { No association with } \\
\text { cancer risk and } \\
\text { survival }\end{array}$ & $\begin{array}{l}\text { Cancer risk, No association with RR vs } \\
\text { Lymph node cancer risk Increase QQ+RQ }\end{array}$ \\
\hline
\end{tabular}

Res metastasis risk of lymph node 5.74 metastasis in RR

\begin{tabular}{|l|l|l|l|l|l|l|l|l|}
\hline Tang Y & $\begin{array}{l}\text { Clin } \\
\text { Cancer } \\
\text { Res }\end{array}$ & China & P574R & Sequencing & $74 / 100$ & $\begin{array}{l}\text { Cancer risk, } \\
\text { Lymph node } \\
\text { metastasis }\end{array}$ & $\begin{array}{l}\text { No association with } \\
\text { cancer risk } \\
\text { Increase risk of } \\
\text { lymph node metas- } \\
\text { tasis in PP }\end{array}$ & $\begin{array}{l}\text { PP vs } \\
\text { RR+PR } \\
4.17\end{array}$ \\
\hline
\end{tabular}

Krish- Ind J India $\quad-1562 \mathrm{C} / \mathrm{T} \quad$ Tetra-primer 140/132 Cancer risk, Increased T allele

naveni Clin amplification Epidemiol- in cancer, smoking

D 2012 Bio- refrac- ogy of risk enhanced cancer

chemis- $\quad$ tory mutation factor risk in TT than CC

$\begin{array}{lll}\text { try } & \text { PCR } & \text { genotype }\end{array}$

\begin{tabular}{|c|c|c|c|c|c|c|c|c|c|}
\hline $\begin{array}{l}\text { Lee TY } \\
2013\end{array}$ & $\begin{array}{l}\text { Hepato- } \\
\text { gastro } \\
\text { enterol- } \\
\text { ogy }\end{array}$ & Tiwan & $-1562 \mathrm{C} / \mathrm{T}$ & PCR-RFLP & $263 / 354$ & $\begin{array}{l}\text { Cancer risk, } \\
\text { Invasion, } \\
\text { Survival }\end{array}$ & $\begin{array}{l}\text { Increased cancer } \\
\text { risk in female, In- } \\
\text { creased lymphnode } \\
\text { metastasis and } \\
\text { serosal invasion, } \\
\text { No difference in } \\
\text { survival }\end{array}$ & $\begin{array}{l}\text { CT+TT vs } \\
\text { CC } 2.12 \\
3.47(\mathrm{HR}) \\
2.31 \text { (HR) }\end{array}$ & $\begin{array}{l}0.02 \\
<0.001 \\
0.003\end{array}$ \\
\hline $\begin{array}{l}\text { Zhang } \\
\text { Wei- } \\
\text { qiang }\end{array}$ & $\begin{array}{l}\text { China } \\
\text { J of } \\
\text { Modern } \\
\text { Medi- } \\
\text { cine }\end{array}$ & China & $-1562 \mathrm{C} / \mathrm{T}$ & PCR-RFLP & $170 / 200$ & $\begin{array}{l}\text { Cancer risk, } \\
\text { Lymphatic } \\
\text { metastasis, } \\
\text { Tumor stag- } \\
\text { ing }\end{array}$ & $\begin{array}{l}\text { No link with cancer } \\
\text { risk, Increased lym- } \\
\text { phatic metastasis in } \\
\mathrm{CT}+\mathrm{TT},>\mathrm{CT}+\mathrm{TT} \text { in } \\
\text { higher stage. }\end{array}$ & & \\
\hline $\begin{array}{l}\text { KH } \\
\text { Hung } \\
2009\end{array}$ & $\begin{array}{l}\text { Helico- } \\
\text { bacter }\end{array}$ & Tiwan & $-1562 \mathrm{C} / \mathrm{T}$ & PCR-RFLP & $\begin{array}{l}296 / 0 \\
\text { (Hp-in- } \\
\text { fected) }\end{array}$ & $\begin{array}{l}\text { Risk of } \\
\text { Intestinal } \\
\text { metaplasia }\end{array}$ & $\begin{array}{l}\text { Combination of } \\
\text { MMP9 }-1562 \mathrm{C} / \mathrm{T} \\
\text { and TIMP1-372 } \\
\mathrm{CC} / \mathrm{T}+\mathrm{CT} / \mathrm{T} \text { in in- } \\
\text { testinal metaplasia }\end{array}$ & & \\
\hline
\end{tabular}

A comprehensive literature search was done using electronic data bases of Pubmed, ISI web of knowledge, Medline and google scholar in terms of MMP9 -1562 C/T polymorphism and risk of gastric cancer, serosae invasion, lymphnode metastasis, survival, tumor staging

are different between Asian and Caucasian populations (Joos et al., 2002).

\section{MMP9 Polymorphism in Various Populations}

The gastric cancer rates show marked geographical variation, with high-risk areas in Japan, China, eastern Europe and certain countries in Latin America. Lowrisk population is seen among whites in North America, India, Philippines, most countries in Africa, some western European countries and Australia. In India, the number of new stomach cancer cases in 2001 was estimated to be approximately $35,675(n=23,785$ in men; 11,890 in women) (Dikshit et al., 2011). These differences in incidence rates can be attributed to many factors but refer particularly to differences in dietary habits, infection by Helicobacter Pylori and presence of intra individual genetic predisposition factors. Like most cancers, gastric cancer has a complex multistep etiology that involves both environmental and genetic factors. MMP9 is frequently overexpressed in gastric cancer and the gene expression mainly ntrolled at transcriptional level. Hence, the presence of SNP within promoter region markedly influences gene expression as well as disease susceptibility. As gastric cancer showed marked geographical variation and mostly prominent among Asian population, most of the studies concerning MMP9 polymorphism and gastric cancer risk were conducted in Asian population. 
Zhang et al investigated the association of functional polymorphisms in the MMP2 and MMP9 genes with risk of gastric cancer in a Chinese population. The effectmodified model was used to evaluate the gene-gene interaction. They did not find significant association between MMP9 -1562C/T polymorphism and risk of gastric cancer. However, the polymorphisms in these two genes seem to display a gene-gene interaction, with a high cancer risk for subjects carrying both MMP-2 -1306CC and MMP9 -1562TT or CT genotypes compared with those carrying both MMP-2 -1306TT or CT and MMP91562 CC genotypes (Zhang et al., 2004b).

Matsumura et al reported -1562C/T SNP in the MMP9 promoter affecting tumor progression and invasive phenotype of gastric cancer among Japanese population (Matsumura et al., 2005). They found that genotype frequencies in gastric cancer patients were similar to those in control subjects, however the presence of T allele at MMP9 -1562 site was significantly associated with increase tumor invasion, more advance stage of cancer, lymphatic invasion and deeper submucosal infiltration in gastric cancer patients. On the other hand, Kubben et al did not find any positive association between MMP9 $-1562 \mathrm{C} / \mathrm{T}$ polymorphism and gastric cancer risk among Caucasian population (Kubben et al., 2006). Association of two non-synonymous SNP(R279Q and P574R) located at the exon region of MMP9 gene on the occurrence and progression of gastric cancer has been studied by Tang et al in Chinese population (Tang et al., 2008). These two coding region polymorphism are associated with amino acid substitution in the MMP9 protein. R279Q SNP substitute an Arg to Gln in fibronectin type II domain and P574R SNP is associated with Pro to Arg substitution within the hemopexin domain. A significant association between the above two non-synonymous MMP9 polymorphisms with lymph node metastasis in gastric cancer, especially with the diffuse type was observed suggesting specific role of MMP9 protein in lymph node metastases. Kim et al reported that the allele and genotype frequencies of MMP9 rs 17576 (Table 2) were not associated with the development of gasric cancer and lymph node metastasis in Korean population (Kim et al., 2011). Significant correlation with MMP9 -1562 C/T or T/T genotype and higher risk of gastric cancer among female in Taiwan was documented by Lee et al (Lee et al., 2013). Stratified analysis showed only elderly females with $\mathrm{T}$ allele had higher risk of gastric cancer. Lee et al concluded that MMP9 -1562 promoter polymorphism with $\mathrm{T}$ allele may be used as a marker to predict gastric cancer development in female subjects, especially in the elderly. In Indian scenario, Krishnaveni et al showed an increased frequency of $\mathrm{T}$ allele in the diseased compared to control subjects among south Indian population (Venkateshwari et al., 2011). We conducted a hospital based case control study to evaluate the association of MMP9 promoter polymorphism with gastric cancer risk in east Indian population. We found that MMP9 -1562 $\mathrm{C} / \mathrm{T}$ polymorphism is significantly associated with gastric cancer risk (OR-1.324, 95\% CI-1.24-2.59) in east Indian case- control cohort $(n=463)$ (Table 1$)$.
DOI:http://dx.doi.org/10.7314/APJCP.2015.16.17.7393 An Overview of MMP9 Polymorphism and Gastric Cancer Risk MMP9 as a Prognostic Marker in Gastric Cancer: A Step towards Personalized Diagnostics

Improvement in prognostic and diagnostic tools has offered excellent long-term survival for early gastric cancer; however, the prognosis of advanced cancer still remains poor. Discovery and application of biomarkers that incorporate with traditional cancer diagnosis, staging, and prognosis could largely help to improve early diagnosis and patient care. Basic cancer research has mainly focused on mutations in cancer cells that result in either gain-of-function in oncogenes or loss-of-function in tumour-suppressor genes. Analyses of gene expression profiles and genetic polymorphisms are avenues to identify novel prognostic factors. The DNA polymorphisms can exert allele-specific effects on the regulation of gene expression or function of the encoded protein. Therefore, DNA polymorphism can explain individual differences in various biological traits and in susceptibility to disease and also help in personalized therapeutics.

The prognostic value of MMP9 expression by tumor tissues has been reported in relation to a variety of cancers (McDonnell and Matrisian, 1990; Kallakury et al., 2001; Baker and Leaper, 2003; Ozalp et al., 2003; Tanioka et al., 2003; Sakata et al., 2004) including gastric cancer (Tang et al., 2008). MMP9 (Gelatinase-B) has been localized immunohistochemically in parietal cells, surface cells, and alveolar epithelial cells of normal human and rabbit gastric mucosa (Hellmig et al., 2006). Immunohistochemical and in situ hybridization studies as well as quantitative assays have demonstrated that gastric carcinomas contain enhanced amounts of MMPs (Nomura et al., 1995; Honda et al., 1996). Gain of 20q12-1q13, where MMP9 is located, has been reported to be one of the most frequent regions with genomic gains in gastric lymph node metastasis of gastric cancer (Tang et al., 2008).

Expression of MMP9 is regulated primarily at the level of transcription, where the promoter of the gene responds to different regulators such as interleukin-1, platelet-derived growth factor, tumor necrosis factor- $\alpha$, and epidermal growth factor (Zhang et al., 1999). Recent advances in genomic science have enabled us to uncover the molecular mechanism of stomach carcinogenesis and its progression. Allele specific effect of MMP9 -1562 $\mathrm{C} / \mathrm{T}$ site may also influence the timing and choice of chemotherapy for patients suffering from gastric cancer. Analysis of genetic polymorphisms will give information on cancer risk and sensitivity to chemotherapy, and predict the biological behavior of the cancer. Further study of the biological ramifications of these polymorphisms may add to our understanding of the biology of gastric cancer and provide potential foci for targeted therapies and may one day be used as a risk assessment tool. The data of MMP9 SNP and gastric cancer might have utility in future development of approaches for identifying atrisk individuals and strategies to optimize treatment. A combination of examinations of different SNPs in different gene can not only foretell the patient's prognosis but can also clarify the characteristics of the individual tumor and 


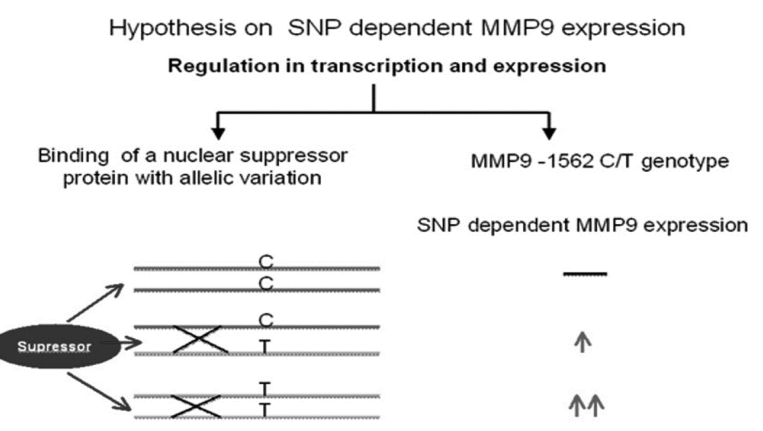

Figure 4. Model of Novel Mechanism of $\mathbf{T}$ allele Dependent Over Expression of MMP9. For T allele dependent overexpression of MMP9 to occur , the genome must contain a $\mathrm{T}$ allele, either as a heterozygote or homozygote. The transcription factor(s) (TF) that is able to bind to $\mathrm{T}$ allele becomes expressed and/or unregulated and augments transcription. If the $\mathrm{C}$ allele is present, then a repressor occupies the site and transcription factors are unable to bind and thus allowing no SNP dependent transcription

person, which are directly connected with personalized medicine.

\section{Conclusions}

The SNP based study provides a promising aspect of identifying susceptibility genes of complex disease, but the selection of SNPs should be appropriate for such type of study. As our understanding of SNPs in MMP9 promoter broadens, the opportunities to apply that knowledge to individualize therapy for cancer patients with more targeted therapies will continue to increase as well. Better understanding of SNPs in MMP9 promoter might help in personalized medicine as a particular SNP with other genetic lesion can predict the gastric cancer risk more accurately for an individual. MMP9 -1562 $\mathrm{C} / \mathrm{T}$ could be an important SNP for increased expression of MMP9 in a particular locality. A nuclear repressor protein which generally binds to the MMP9 promoter in presence of $\mathrm{C}$ allele at the position -1562 and keeps the promoter transcriptionally less active, thus no longer able to bind when $\mathrm{C}$ allele is replaced by $\mathrm{T}$ allele and induce high MMP9 promoter activity (Figure 4). Invasion and metastasis are critical determinants of cancer morbidity and MMP9 plays major role in both of these. A substantial fraction of regulatory genetic variants influence gene expression at all levels from mRNA to steady-state protein abundance (Battle et al., 2015). Understanding how genetic variation impacts the regulation of gene expression may provide better understanding for links between genetic and phenotypic variation.

\section{Acknowledgements}

Sugreev Verma is recipient of senior research fellowship, University Grant Commission; Kausik Kesh is recipient of senior research fellowship, Council of Scientific and Industrial Research, India. The authors are thankful to director of CSIR-IICB Kolkata for overall support. The funding from INDEPHT is acknowledged. The authors acknowledge Dr. Sanjib Dey for providing
MMP9 polymorphism literature. The study protocols were approved by the Ethical Review Boards of the SGCCR institute and human Ethics Committee of CSIR-Indian Institute of Chemical Biology, Kolkata, India. The authors have declared that no conflict of interest exists regarding this work.

\section{References}

Baker EA, Leaper DJ (2003). The plasminogen activator and matrix metalloproteinase systems in colorectal cancer: relationship to tumour pathology. Eur J Cancer, 39, 981-8.

Battle A, Khan Z, Wang SH, et al (2015). Genomic variation. Impact of regulatory variation from RNA to protein. Science, 347, 664-7.

Behrens P, Rothe M, Wellmann A, et al (2001). The Ets-1 transcription factor is up-regulated together with MMP 1 and MMP 9 in the stroma of pre-invasive breast cancer. $J$ Pathol, 194, 43-50.

Choi IS, Wu TT (2005). Epigenetic alterations in gastric carcinogenesis. Cell Res, 15, 247-54.

Crew KD, Neugut AI (2006). Epidemiology of gastric cancer. World J Gastroenterol, 12, 354-62.

Dikshit RP, Mathur G, Mhatre S, et al (2011). Epidemiological review of gastric cancer in India. Indian J Med Paediatr Oncol, 32, 3-11.

Fanjul-Fernández M, Folgueras AR, Cabrera S, et al (2010). Matrix metalloproteinases: Evolution, gene regulation and functional analysis in mouse models. Biochimica et Biophysica Acta (BBA) - Molecular Cell Research, 1803, 3-19.

Ferlay J, Shin HR, Bray F, et al (2010). Estimates of worldwide burden of cancer in 2008: GLOBOCAN 2008. Int J Cancer, 127, 2893-917.

Forget MA, Desrosiers RR, Beliveau R (1999). Physiological roles of matrix metalloproteinases: implications for tumor growth and metastasis. Can J Physiol Pharmacol, 77, 465-80.

Fox JG, Wang TC (2007). Inflammation, atrophy, and gastric cancer. J Clin Invest, 117, 60-9.

Ghilardi G, Biondi ML, Mangoni J, et al (2001). Matrix metalloproteinase- 1 promoter polymorphism $1 \mathrm{G} / 2 \mathrm{G}$ is correlated with colorectal cancer invasiveness. Clin Cancer Res, 7, 2344-6.

Gum R, Lengyel E, Juarez J, et al (1996). Stimulation of 92-kDa gelatinase B promoter activity by ras is mitogen-activated protein kinase kinase 1-independent and requires multiple transcription factor binding sites including closely spaced PEA3/ets and AP-1 sequences. J Biol Chem, 271, 10672-80.

Hannenhalli S (2008). Eukaryotic transcription factor binding sites--modeling and integrative search methods. Bioinformatics, 24, 1325-31.

Hellmig S, Ott S, Rosenstiel P, et al (2006). Genetic variants in matrix metalloproteinase genes are associated with development of gastric ulcer in H. Pylori infection. Am J Gastroenterol, 101, 29-35.

Hirakawa S, Lange EM, Colicigno CJ, et al (2003). Evaluation of genetic variation and association in the matrix metalloproteinase 9 (MMP9) gene in ESRD patients. Am J Kidney Dis, 42, 133-42.

Honda M, Mori M, Ueo H, et al (1996). Matrix metalloproteinase-7 expression in gastric carcinoma. Gut, 39, 444-8.

Hu Z, Huo X, Lu D, et al (2005). Functional polymorphisms of matrix metalloproteinase- 9 are associated with risk of occurrence and metastasis of lung cancer. Clin Cancer Res, 11, 5433-9. 
Inoue T, Yashiro M, Nishimura S, et al (1999). Matrix metalloproteinase-1 expression is a prognostic factor for patients with advanced gastric cancer. Int J Mol Med, 4, 73-7.

Inuzuka K, Ogata Y, Nagase H, et al (2000). Significance of coexpression of urokinase-type plasminogen activator, and matrix metalloproteinase 3 (stromelysin) and 9 (gelatinase B) in colorectal carcinoma. J Surg Res, 93, 211-8.

Joos L, He JQ, Shepherdson MB, et al (2002). The role of matrix metalloproteinase polymorphisms in the rate of decline in lung function. Hum Mol Genet, 11, 569-76.

Kallakury BV, Karikehalli S, Haholu A, et al (2001). Increased expression of matrix metalloproteinases 2 and 9 and tissue inhibitors of metalloproteinases 1 and 2 correlate with poor prognostic variables in renal cell carcinoma. Clin Cancer Res, 7, 3113-9.

Kanamori Y,Matsushima M,Minaguchi T,etal (1999). Correlation between expression of the matrix metalloproteinase-1 gene in ovarian cancers and an insertion/deletion polymorphism in its promoter region. Cancer Res, 59, 4225-7.

Kim JH, Pyun JA, Lee KJ, et al (2011). [Study on association between single nucleotide polymorphisms of MMP7, MMP8, MMP9 genes and development of gastric cancer and lymph node metastasis]. Korean J Gastroenterol, 58, 245-51.

Kohn EC, Liotta LA (1995). Molecular insights into cancer invasion: strategies for prevention and intervention. Cancer Res, 55, 1856-62.

Kubben FJ, Sier CF, Meijer MJ, et al (2006). Clinical impact of MMP and TIMP gene polymorphisms in gastric cancer. $\mathrm{Br}$ J Cancer, 95, 744-51.

Kundu P, Mukhopadhyay AK, Patra R, et al (2006). Cag pathogenicity island-independent up-regulation of matrix metalloproteinases- 9 and -2 secretion and expression in mice by Helicobacter pylori infection. J Biol Chem, 281, 34651-62.

Langers AM, Verspaget HW, Hommes DW, et al (2011). Singlenucleotide polymorphisms of matrix metalloproteinases and their inhibitors in gastrointestinal cancer. World $J$ Gastrointest Oncol, 3, 79-98.

Lee SH, Han SK, Shim YS, et al (2009). Effect of matrix metalloproteinase- $9-1562 \mathrm{C} / \mathrm{T}$ gene polymorphism on manifestations of pulmonary tuberculosis. Tuberculosis (Edinb), 89, 68-70.

Lee TY, Yu CC, Wu CC, et al (2013). MMP-9 -1562 Promoter Polymorphism Associated with Gastric Cancer Risk in Females. Hepatogastroenterology, 60.

Libermann TA, Zerbini LF (2006). Targeting transcription factors for cancer gene therapy. Curr Gene Ther, 6, 17-33.

Maeda S, Haneda M, Guo B, et al (2001). Dinucleotide repeat polymorphism of matrix metalloproteinase- 9 gene is associated with diabetic nephropathy. Kidney Int, 60, 1428-34.

Matsumura S, Oue N, Nakayama H, et al (2005). A single nucleotide polymorphism in the MMP-9 promoter affects tumor progression and invasive phenotype of gastric cancer. J Cancer Res Clin Oncol, 131, 19-25.

McDonnell S, Matrisian LM (1990). Stromelysin in tumor progression and metastasis. Cancer Metastasis Rev, 9, 305-19.

Murthy NS, Chaudhry K, Rath GK (2008). Burden of cancer and projections for 2016, Indian scenario: gaps in the availability of radiotherapy treatment facilities. Asian Pac J Cancer Prev, 9, 671-7.

Nakayama T, Ito M, Ohtsuru A, et al (1996). Expression of the Ets-1 proto-oncogene in human gastric carcinoma: correlation with tumor invasion. Am J Pathol, 149, 1931-9.

Nomura H, Sato H, Seiki M, et al (1995). Expression of membrane-type matrix metalloproteinase in human gastric
DOI:http://dx.doi.org/10.7314/APJCP.2015.16.17.7393

An Overview of MMP9 Polymorphism and Gastric Cancer Risk carcinomas. Cancer Res, 55, 3263-6.

Ozalp S, Tanir HM, Yalcin OT, et al (2003). Prognostic value of matrix metalloproteinase-9 (gelatinase-B) expression in epithelial ovarian tumors. Eur J Gynaecol Oncol, 24, 417-20.

Pinto LA, Depner M, Klopp N, et al (2010). MMP-9 gene variants increase the risk for non-atopic asthma in children. Respir Res, 11, 23.

Sakata K, Satoh M, Someya M, et al (2004). Expression of matrix metalloproteinase 9 is a prognostic factor in patients with non-Hodgkin lymphoma. Cancer, 100, 356-65.

Sentani K, Oue N, Sakamoto N, et al (2008). Gene expression profiling with microarray and SAGE identifies PLUNC as a marker for hepatoid adenocarcinoma of the stomach. Mod Pathol, 21, 464-75.

Shimajiri S, Arima N, Tanimoto A, et al (1999). Shortened microsatellite $\mathrm{d}(\mathrm{CA}) 21$ sequence down-regulates promoter activity of matrix metalloproteinase 9 gene. FEBS Lett, 455, 70-4.

Sier CF, Kubben FJ, Ganesh S, et al (1996). Tissue levels of matrix metalloproteinases MMP-2 and MMP-9 are related to the overall survival of patients with gastric carcinoma. Br J Cancer, 74, 413-7.

Sternlicht MD, Werb Z (2001). How matrix metalloproteinases regulate cell behavior. Annu Rev Cell Dev Biol, 17, 463-516.

Swarnakar S, Ganguly K, Kundu P, et al (2005). Curcumin regulates expression and activity of matrix metalloproteinases 9 and 2 during prevention and healing of indomethacininduced gastric ulcer. J Biol Chem, 280, 9409-15.

Tan SY, Wang JY, Shen L, et al (2007). Relationship between preoperative staging by endoscopic ultrasonography and MMP-9 expression in gastric carcinoma. World $J$ Gastroenterol, 13, 2108-12.

Tang Y, Zhu J, Chen L, et al (2008). Associations of matrix metalloproteinase-9 protein polymorphisms with lymph node metastasis but not invasion of gastric cancer. Clin Cancer Res, 14, 2870-7.

Tanioka Y, Yoshida T, Yagawa T, et al (2003). Matrix metalloproteinase-7 and matrix metalloproteinase- 9 are associated with unfavourable prognosis in superficial oesophageal cancer. Br J Cancer, 89, 2116-21.

Venkateshwari A, Sri Manjari K, Krishnaveni D, et al (2011). Role of Plasma MMP 9 levels in the pathogenesis of chronic pancreatitis. Indian J Clin Biochem, 26, 136-9.

Woo M, Park K, Nam J, et al (2007). Clinical implications of matrix metalloproteinase- $1,-3,-7,-9,-12$, and plasminogen activator inhibitor-1 gene polymorphisms in colorectal cancer. J Gastroenterol Hepatol, 22, 1064-70.

Wu CW, Chi CW, Lin WC (2002). Gastric cancer: prognostic and diagnostic advances. Expert Rev Mol Med, 4, 1-12.

Xing LL, Wang ZN, Jiang L, et al (2007). Matrix metalloproteinase-9-1562C $>$ T polymorphism may increase the risk of lymphatic metastasis of colorectal cancer. World J Gastroenterol, 13, 4626-9.

Ye S, Eriksson P, Hamsten A, et al (1996). Progression of coronary atherosclerosis is associated with a common genetic variant of the human stromelysin-1 promoter which results in reduced gene expression. $J$ Biol Chem, 271, 13055-60.

Zhang B, Ye S, Herrmann SM, et al (1999). Functional polymorphism in the regulatory region of gelatinase $\mathrm{B}$ gene in relation to severity of coronary atherosclerosis. Circulation, 99, 1788-94.

Zhang J, Jin X, Fang S, et al (2004a). The functional SNP in the matrix metalloproteinase-3 promoter modifies susceptibility and lymphatic metastasis in esophageal squamous cell carcinoma but not in gastric cardiac adenocarcinoma. Carcinogenesis, 25, 2519-24. 
Sugreev Verma et al

Zhang QW,Liu L, Chen R, et al (2012). Matrix metalloproteinase-9 as a prognostic factor in gastric cancer: a meta-analysis. Asian Pac J Cancer Prev, 13, 2903-8.

Zhang S, Li L, Lin JY, et al (2003). Imbalance between expression of matrix metalloproteinase- 9 and tissue inhibitor of metalloproteinase- 1 in invasiveness and metastasis of human gastric carcinoma. World J Gastroenterol, 9, 899-904.

Zhang XM, Miao XP, Xiong P, et al (2004b). [Association of functional polymorphisms in matrix metalloproteinase-2 (MMP-2) and MMP-9 genes with risk of gastric cancer in a Chinese population]. Ai Zheng, 23, 1233-7. 